\title{
Sarcoma of the Orbit cM1 TNM Finding v7
}

National Cancer Institute

\section{Source}

National Cancer Institute. Sarcoma of the Orbit cM1 TNM Finding v7. NCI Thesaurus.

Code C88826.

Sarcoma of the orbit with distant metastasis. (from AJCC 7th Ed.) 